の容疑は濃厚となる。

「毒ガスサリン」と断定されたのは, 事件発生 1 週間後 の 7 月 3 日のことだった。そこでマスコミに登場した化 学者のコメントが, 先述した内容だったのである。

一般に，サリン事件とオウム真理教との関係が問われ るようになったきっかけは，今年正月元旦の読売新聞の スクープである。「山梨県上九一色村で異臭騒ぎ」と報 じ, 松本サリンの時と同じ, サリン生成残留物が発見さ れたことを明らかにした。読売紙上ではオウムについて 触れていなかったが, 直後に発売された週刊誌では, 才 ウムとの関係について言及していた。より背景を詳しく 報じたのが，週刊新潮(1月19 日号)である。松本市内 で，オウムが取得した土地をめぐり地元住民との間で訴 訟が起こっていた。その裁判の担当判事が, サリンの被 害に遭っていた，と書いた。事件当時には，そうした背 景については全くわかっていなかった。
後日，これも小誌で記事にしたが，松本サリン事件当 時, あるテレビ局の依頼で現地調査した元東京大学農学 部の森謙治教授が,「裁判官宿舍の松の木も不自然な枯 れ方をしている」と既に指摘されていた。が, テレビで は, 第一通報者宅の部分だけ放送され, 裁判官宿舎の指 摘はカットされたという。

我々の仕事では, 専門家の助言が不可欠である。今回 の事件でも, 多くの有機合成化学者の協力を得たが, 理 解の仕方に問題があったと思うこと，しきりである。

(平成 7 年 7 月 24 日受理)

\title{
サリン事件に関わって一捜査は新型犯罪に対応しうるか
}

\section{加藤 博* \\ Got involved in the sarin cases. Can crime investigations cope with crimes of new type?}

\author{
Hiroshi $\mathrm{K}_{\mathrm{ATO}} *$
}

松本での有毒ガス発生後，筆者のもとにはごく早い段 階で，あの有毒ガスがホスホン酸エステルであるとの情 報が報道関係から伝えられていたが, 毒物がサリンと「推 定される」ことが公表されたのは事件後 6 日目 $(7$ 月 3 日)であった。捜査の妨げになる恐れから警察が公表を ためらったのではということが筆者の杞憂に過ぎず，少 なくとも医療関係機関には速やかにこの情報が伝達され ていたことも願っていた。しかし医療関係者による報 告 ${ }^{1)}$ には， 7 月 3 日に毒物がサリンと判明と記載されて いる。このことに関して警察当局は「7 月 3 日に県衛生 公害研究所(衛公研)から連絡を受け, 直ちに県警科学捜 査研究所(科捜研)でも検査して同様の結果を得たので公 表した」」)と述べている。一方, 衛公研では「29 日の昼ご ろ分析データがサリンと一致したが, さらに確証が得ら れるまで公表するのは無理だった」と述べている。し かし29 日の時点での情報が警察にも届いていないと言 うことがありうるだろうか。極微量の有毒成分の抽出に 成功したことは称賛に值するが, いったん検出限界濃度 以上の検体を確保できれば，GC-MS 付属のデータベー
スから毒物の第一候補としてサリンが自動的に検索され たはずである。衛公研の報告書年に記載されている補助 的確認手段である CI-MS による分子量測定, GC の retention index の比較に長時間を要したとは考え難い。毒 物の正体を公表するのに警察の追試と同意がなぜ必要な のだろうか。科捜研で何日も努力しても検出されなかっ たものが，なぜ衛公研からの情報でたちどころに検出さ れたのだろうか。 7 月 3 日の(緊急)記者会見は時間を繰 り上げて午前 9 時から行われているので，報道機関への 連絡等を考えると当日(日曜日)衛公研から連絡を受けた 後で追試実験を行う時間があり得たであろうか。毒物成 分の速やかな公表を阻んだものは何だったのであろう 加。

サリンとともに当然検出されるはずの副生物や分解物 についても警察は一切のコメントを拒否してきた。これ らの情報を提供することでどのような捜査上の支障が生 じると警察は考えているのであろうか。このような無意 味な秘密主義の結果として, 一時期, 松本で発生した毒 物はサリンではなかったとの(一部の化学者をも含む人 
達の)見解が報道をにぎわしていた。これらの見解は GC-MS を GC と混同されたり, サリンの加水分解速度 の濃度 $(\mathrm{pH})$ 依存性の配慮の欠如に由来するものである が，そのために引き起こされる住民の不安を警察は考え なかったのであろうか。

警察の地道な捜査の一環として, 事件に関連した薬品 の流通経路の追跡があった。筆者は「その気になればい くらでもだませるから, 関連する複数の種類の薬品購入 者，あるいは 1 種類でも現金購入者だけを徹底的に追及 する方がずっと効率的だ」との不謹慎なコメントをした ことがある。今回の被疑者はこの条件をすべて満たして いたようである。しかも想像を絶する大量というおまけ 付きで! 周辺土壌の残留物との関連も含めて, 警察が全 力をここに傾注していたら，あるいは地下鉄での惨事は 起こらないで済んだのではないだろうか。

河野氏にかけられた不幸な疑惑に関してはあえて触れ ないでおくが, それでは現在のスタッフでは警察は新型 の犯罪に対処し得ないのだろうか。筆者はそうは思わな
い。科捜研は優秀な人材を抱えているし，松本の事件で 組織された化学捜査班のスタッフも一般的には十分に科 学的思考のできる人達であった。必須なことは捜査の中 心になる人達が, 専門家の意見に謙虚に耳を傾けること であろう。第一線捜查員の努力を無にしないためにも。

1）松本市地域包括医療協議会,「松本市有毒ガス中毒 調查報告書」, 1995 年

2）長野県議会での長野県警本部長の答弁。朝日新聞 長野地方版, 1995 年 6 月 29 日

3）朝日新聞長野地方版, 1995 年 6 月 29 日

4）長野県衛生公害研究所,「松本市における有毒ガス 中毒事故の原因物質究明に関する報告書」, 1995 年

\title{
サリン事件に関わって一有機合成化学者育成の在り方を考える
}

\author{
田坂 興 覀*
}

\section{Sarin incident-Need for reform of chemical education}

\author{
Koa TASAKA*
}

昨年の 6 月末，松本であの忌まわしい出来事が起こっ た翌日に，ある新聞記者から電話がかかってきた。松本 で有機リン化合物によると思われる中毒症状を示す死 者, 患者が出たが, 農薬だとしたらどんなものが考えら れるか, との問い合わせであった。状況を聞いてみる と, 毒物はガス状で広がったようであるし, 建物の 2 階 以上でも死者を含む急性中毒症状が出ているという。そ れは, 現在日本で使われている有機リン系農薬では説明 がつかないと思われたので,「農薬ではなく, サリンや タブン等の毒ガスの可能性があるかも知れません」と答 えて電話を切った。数日後に警察は,「現場付近の池の 水の分析から, サリンが使われたと推定される」と発表 したので, その時点から, 新開・雑誌社, テレビ局等か ら問い合わせの電話がひっきりなしにかかってくる羽目 になった。

もともと，筆者はサリン・タブンといった毒ガスを 扱ったことはない。東工大での卒業研究から大学院修士
課程まで指導を受けた向山研究室で, 当時博士課程在学 中の畑辻明氏のもとで, Perkow 反応を用いる新しいリ ン酸化剤の開発をテーマとする研究を行っていたが, 三 価のリン化合物として亜リン酸トリメチルの合成を行っ たことはある。殺されたオウムの村井氏は, 松本の事件 の直後に山梨県上九一色村で起きた「異臭騒ぎ」は, 教団 が農薬のDDVPを製造するための第一段階として合成 した亜リン酸トリメチルが漏れたためだと説明してい る。この亜リン酸トリメチルは確かにひどい悪臭で, 東 工大の本館 3 階の「角べや」と称する実験室で, 三塩化り ンからこれを合成した時には，その「鼻の曲がるような」 猛烈な悪臭に悩まされたものであった。この亜りン酸卜 リメチルを, オウムの科学者達は, 少量のヨウ化メチル によってメチルホスホン酸ジメチルとし(Arbuzov 反 応), さらにこれを原料の三塩化リンとクロラール合成 のために作ったと村井氏が言う塩素によりジクロリド に, そしてフッ化ナトリウムを(多分, フッ化水素として) 